\title{
A Simple Analysis and Critical Reflection of the Morphology and Syntax of Acehnese Language
}

\author{
Wael Abdulrahman Almurashi \\ A Lecture Assistant \\ Department of Languages and Translations \\ Faculty of Science and Arts \\ Taibah University \\ Kingdom of Saudi Arabia
}

Received: March 11, 2016 Accepted: March 30, 2016 Published: April 2, 2016

doi:10.5296/jsel.v4i1.9249 URL: http://dx.doi.org/10.5296/jsel.v4i1.9249

\begin{abstract}
There are specific morphology and syntax rules that accompany every language and contribute to the uniqueness of each language. When people learn a new language, for example, they must apply the grammar rules associated with it if they want to be effective communicators. In Indonesia, within the province of Aceh, a good number of local languages are spoken. One such language, which the people living in the northern part of Sumatra, Indonesia, speak, is known as Acehnese. The major objective of this study is to conduct an evaluation and a critical reflection of Acehnese that will describe the language's morphology and syntax in full detail. One native speaker studying for a Doctor of Philosophy at Adelaide University, by the name of Zulfadli Aziz, provided the data used for this research work. The International Phonetic Alphabet (IPA) symbols were utilised in identifying and transcribing all instances involved in the data. Regarding Acehnese morphology, several aspects have been explained in detail, namely, pronouns, tenses, plurality, reduplication, affixes, classifiers, and articles. This study also covers some aspects in term of syntax such as, word order, flexibility, and intonation. Many identifiable differences exist between Acehnese and Arabic, for instance, the word order in Arabic is verb-subject-object (VSO) whereas Acehnese has an SVO order. Furthermore, the paper makes recommendations that could easily be applied to make the experience of learning Acehnese easy.
\end{abstract}

Keywords: Acehnese, Arabic, Morphology, Syntax, Affixes, Classifiers, Intonation, reduplication 


\section{Introduction}

Every language has its own morphology and syntax rules that makes it unique. Learning a new language means incorporating grammar rules, as well as other skills, in order to become an effective communicator. In the Aceh province of Indonesia, a significant number of languages abound. One spoken by the people living in the northern part of Sumatra, Indonesia, is Acehnese. This particular language is spoken by a population of approximately three-and-a-half million individuals (Lewis 2009). In terms of the official context, such as media and work as well as administration, Acehnese is not broadly utilised since the official language used in Indonesia is Bahasa Indonesia. Nonetheless, the use of Acehnese can be seen in informal contexts, more specifically in urban places, such as Banda Aceh (Alamsyah et al. 2011). Unfortunately, few studies of this language have been condlucted. The data of Acehnese presented here have been elicited from one Acehnese speaker, Zulfadli Aziz, a Ph.D. student at Adelaide University.

The purpose of this paper is to analyze and produce a critical reflection on the Acehnese morphology and syntax, based on the researcher's own experience, with a strong contrastive linguistics focus. It will also address the following issues: (1) An analysis of the morphology and syntax of Acehnese, (2) the differences between Acehnese and Arabic language.

\section{An Analysis of the Morphology and Syntax of Acehnese}

\subsection{Morphology}

According to Haspelmath (2002), morphology is the study of word structure. The researcher asserted that morphological analysis typically consists of the identifications of parts of words or more precisely constituents of words (McCarthy 2002). However, Acehnese possesses its unique morphology; it has been explained in detail below.

- Pronouns: Like any language, Acehnese has its own pronouns. As an illustration, it has /lon / = I; /yih/ = he, she, and it; /yih/ = we; /awə2/ = they; /drouh/ = you (singular); and /awadro mandom/ = you (plural) (see Table 1 and 2). However, Acehnese pronouns do not differentiate for gender; that is, the same pronoun may be used for she/he. The example in Table 3 shows that the pronoun for "she" and "he" (in red color) is the same: /yih/. In addition, Acehnese pronouns do not distinguish between singular and plural, except the first person pronouns. This does not mean that the same pronouns can be used for plural pronouns without the help of other words. Second and third person pronouns are usually made plural by adding a word meaning all $=/ \mathrm{mand} \sigma \mathrm{m} /$. For example, Table 4 shows a special word for a single person, or you $=/ \mathrm{drowh} /$, but by adding the word all $=/ \mathrm{mand} \mathrm{m} /$, it becomes "you all" =/awadro mandom/.

- Tenses: Unlike Arabic and English, Acehnese has no verb inflection for tenses (see Table 5). Past or present tense in Acehnese can be understood in context or by the use of certain adverbs of time: $/$ Sinch/ = tomorrow for the present time actions; yesterday $=/ \mathrm{baro} /$; last night $=/$ buklam $/$; last week $=/$ mingu yay kalikot for past time actions. 


\section{$\Lambda$ Macrothink}

- Plurality and reduplication: The plurality of nouns in Acehnese is not indicated by any ending or inflection, but it is sometimes reduplicated to indicate plurality. As an example, Table 6 shows that Acehnese uses the same word twice for the plural of books (/buku buku/), and the noun remains the same whether it is used for the singular or plural sense. However, in Acehnese, not all types of reduplication indicate plurality; they can indicate another function for emphasis. Table 7 shows a speaker trying to assert the number of red cars by reduplicating with the word huge $=$ rəju? rəju?/ and many /mirəh mirəh/.

- Acehnese Affixes: Although Acehnese does not have inflectional morphology, it does have derivational morphology. It has both prefixes and infixes to form words from other words, but there are no suffixes. However, there is a notable number of prefixes, which include nominals, verbs, adverbs, and adjectives. For example, the prefix /beurangka/, which means "ever" or "any," is used to derive nouns. The combination of /beurangka/ with other words produces adverbs as in Table 8. Another prefix in Acehnese is /pu/, which has the function of forming verbs from nouns and adjectives (see Table 8). However, there are some infixes in Acehnese such as /eun/ that have the function of forming nouns from verbs and adjectives. As an example, /pajoh/ is a verb meaning "to eat," but by adding the infix /eun/, it becomes the noun /peunajoh/ and means "food" (see Table 8). Another infix is /eum/, which derives verbs such as /kawe/, which is a noun and means "fishing stick" or "fishing rod"; by adding /eum/, it becomes /keumawe/, or "to go fishing" (see Table 8).

- Classifiers: Like most languages, Acehnese has its own classifiers, which are used to describe a relative shape or to accompany nouns in certain grammatical contexts. For instance, the word /boh/ is considered a quantity modifier (see Table 18). Another classifier is /droe/, which is a quantity classifier to refer to human beings. For example, Sa droe $=$ one person (see Table 9).

- Articles: An article is a word used with a noun to indicate the kind of reference being made by the noun. Unlike many languages, Acehnese does have articles (see Table 10).

\subsection{Syntax}

Unlike morphology, syntax is the study of the internal structure of sentences or phrases. According to Haspelmath (2002 p. 1), "Syntax means sentence construction: how words group together to make phrases and sentences." Acehnese possesses a distinctive syntax.

- Word order and flexibility: Acehnese has the same basic word order as English: SVO, or subject-verb-object. This differs from Arabic (see Table 11). Table 12 shows that the word order in Acehnese is flexible, and words can be moved easily while the meaning remains the same, except classifiers like /boh/. Acehnese is like most languages that do not separate the classifiers from the word.

- Intonation: the intonation of the order of Acehnese seems to be basic: SVO. In this type of sentence, intonation moves smoothly from one level to another. As an example, Table 13 shows that a statement in Acehnese is characterized by an intonation that falls away at the 
end of a sentence whereas Table 14 presents that the intonation is rising gradually at the end of the question.

\section{The Differences between Acehnese and Arabic Language}

Regarding the discriminations between Arabic and Acehnese, Arabic seems significantly different, especially in morphology and syntax. Some of these differences will be briefly clarified in this section. Arabic has many tenses: past, present, and future. This differs from Acehnese. The Arabic word order is verb-subject-object (VSO) whereas Acehnese has an SVO order. Another discrimination is articles: Arabic has several articles to indicate the type of reference being made by the noun. Another difference is that Arabic discriminates between gender in pronouns, verbs, words, and sentence structure. For instance, pronouns like "you" and "they" have specifications for the gender, whether singular and plural. Lastly, Arabic is rich in word derivations. For examples, a lot of words with many different meanings can be derived from a single word. Table 15 presents some derivations that can be produced from one noun, /nawmun/ [نوم], which means “sleeping” (Al-Muhtaseb \& Mellish 1998).

\section{Conclusion}

Acehnese has its own unique morphology and syntax rules, which vary greatly from other languages. However, knowing the morphology and syntax of the target language can help students to understand the nature of the target language system. Additionally, it will help learners to be more creative in creating new words and sentences. This article provided a simple analysis of Acehnese morphology and syntax, which have been explored in detail. After offering a critical reflection of the morphology and syntax of Acehnese, the researcher discussed some differences between Acehnese and Arabic.

The uniqueness of Acehnese morphology and syntax may cause a great deal of difficulty for learners from many language backgrounds. Here are some recommendations to facilitate learning of Acehnese for other language speakers. Learners should pay an attention to the Acehnese morphology and syntax in order to have an idea about the system of the language. Additionally, they should be aware that Acehnese, like any language, has a unique morphology and syntax rules that vary greatly from other native languages. For example, word order in Arabic is VSO, which is different than the Acehnese word order (SVO). Thus, they should not follow their native language rules while learning Acehnese. This is something students should take into account when they intend to learn Acehnese or any language.

\section{References}

Alamsyah, T., Taib, R., \& Idham, M. (2011). Pemilihan bahasa Indonesia sebagai bahasa pertama anak dalam keluarga masyarakat Aceh penutur Bahasa Aceh di Nanggroe Aceh Darussalam (Choosing Indonesian as the children's first language in the family of acehnese 


\section{Macrothink}

community who are acehnese native speakers in Nanggroe Aceh Darussalam). Jurnal Pendidikan Bahasa melayu; Malay Language Education (MyLEJ), 1(2), 31 -44.

Al-Muhtaseb, H., \& Mellish, C. (1998, April). Some differences between Arabic and English: A step towards an Arabic upper model. In 6th International Conference on (pp. 1-12).

Haspelmath, M. (2002). Understanding Morphology. London: Arnold.

Lewis, M. (2009). Ethnologue: Languages of the World (16th edition). Dallas: SIL International. Retrieved on March 4, 2011 from http://www.ethnologue.com/ show_language.asp?code $=$ ace

Carstairs-McCarthy, A. (2002). An introduction to English morphology: words and their structure. Edinburgh University Press.

\section{Appendixes: Tables}

Table 1. Acehnese subject pronouns

\begin{tabular}{|c|c|c|}
\hline $\begin{array}{c}\text { Subject } \\
\text { Pronouns } \\
\text { in } \\
\text { English }\end{array}$ & $\begin{array}{l}\text { Subject } \\
\text { Pronouns } \\
\text { in } \\
\text { Acehnese }\end{array}$ & Example + Meaning \\
\hline I & /lon/ & $\begin{array}{l}\text { /lon lonpugah haba yən gata/ } \\
\text { I talk with you (sing) }\end{array}$ \\
\hline $\mathrm{He}$ & /łih/ & $\begin{array}{l}\text { / Jih lonpugah haba yən gata/ } \\
\text { He talks with you (sing) }\end{array}$ \\
\hline She & /łih/ & $\begin{array}{l}\text { / Jih lonpugah haba yən gata/ } \\
\text { She talks with you (sing) }\end{array}$ \\
\hline It & /fih/ & $\begin{array}{l}\text { / Jih lonpugah haba yən gata/ } \\
\text { it talks with you (sing) }\end{array}$ \\
\hline $\begin{array}{c}\text { You } \\
\text { (singular) }\end{array}$ & /drouh/ & $\begin{array}{l}\text { / drouh gucuggah haba yən lon/ } \\
\text { You talk with me }\end{array}$ \\
\hline They & /awə?/ & $\begin{array}{l}\text { /awə? yən gucurit bhə? nən/ } \\
\text { They talk about it }\end{array}$ \\
\hline $\begin{array}{c}\text { You } \\
\text { (plural) }\end{array}$ & $\begin{array}{l}\text { /awadro } \\
\text { mandom/ }\end{array}$ & $\begin{array}{c}\text { / awadro mandom haba yən lon/ } \\
\text { You talk with me }\end{array}$ \\
\hline $\mathrm{We}$ & $/ \operatorname{taj} /$ & $\begin{array}{l}\text { / tajo yən gщсщrit bhə? nən/ } \\
\text { We talk about it }\end{array}$ \\
\hline
\end{tabular}




\section{Macrothink

Table 2. Acehnese objects pronouns

\begin{tabular}{|c|c|c|}
\hline $\begin{array}{c}\text { Object } \\
\text { Pronouns } \\
\text { in } \\
\text { English }\end{array}$ & $\begin{array}{c}\text { Object } \\
\text { Pronouns } \\
\text { in } \\
\text { Acehnese }\end{array}$ & Example + Meaning \\
\hline me & /lon/ & / awadro mandom haba yən lon/ \\
You talk with me
\end{tabular}

Table 3. Acehnese gender pronouns

\begin{tabular}{|c|c|}
\hline Sentence in English & Sentence in Acehnese \\
\hline She / He is work & /„ih turnəh ๖ikwrwła diSldeh/ \\
\hline
\end{tabular}

Table 4. The pronoun "you," both plural and singular

\begin{tabular}{|c|c|}
\hline Sentence in English & Sentence in Acehnese \\
\hline $\begin{array}{c}\text { You (one person) did not sleep last } \\
\text { night. }\end{array}$ & /drouh hana nu?eh buklam/ \\
\hline You (plural) did not sleep last night & $\begin{array}{c}\text { /awadro mandom hana nu?eh } \\
\text { buklam/ }\end{array}$ \\
\hline
\end{tabular}


Table 5. Acehnese tenses

\begin{tabular}{|c|c|}
\hline Sentence in English & Sentence in Acehnese \\
\hline $\begin{array}{c}\text { Dog will sleep/slept/is sleeping on } \\
\text { the bridge. }\end{array}$ & /əScə JiPeh diwatwh titi/ \\
\hline
\end{tabular}

Table 6. Acehnese plurality and reduplication

\begin{tabular}{|c|c|}
\hline Single & Plural \\
\hline Person $=/$ urwy $/$ & People $=/$ urwy urwy $/$ \\
\hline Dog $=/$ əScə/ & Dogs $=/$ əScə əScə/ \\
\hline Book $=/$ buku/ & Books $/$ buku buku/ \\
\hline
\end{tabular}

Table 7. Acehnese plurality and reduplication for emphasis

\begin{tabular}{|c|c|}
\hline Sentence in English & Sentence in Acehnese \\
\hline There are many red cars. & /moto mirəh mirəh/ \\
\hline There are huge cars. & /moto rəju? roju?/ \\
\hline
\end{tabular}

Table 8. Acehnese affixes

\begin{tabular}{|c|c|c|c|}
\hline Affixes & Example & $\begin{array}{c}\text { Sentence in } \\
\text { Acehnese }\end{array}$ & Meaning \\
\hline prefixes & /Beurangka/ & /Beurangkaban/ & However \\
& & /BeurangkaSoe/ & Whoever \\
& & /Beurangkapeue/ & Whatever \\
& & /peurangkapat/ & Wherever \\
& /pu/ & /putroy/ & want to clarify \\
\hline
\end{tabular}




\begin{tabular}{|c|c|c|c|}
\hline & & & $\begin{array}{c}\text { something } \\
\text { want to explain } \\
\text { something }\end{array}$ \\
\hline infixes & $/$ eun/ & /peunayoh/ & Food \\
& $/$ eum/ & /keumawe/ & To go fishing \\
\hline
\end{tabular}

Table 9. Acehnese classifiers

\begin{tabular}{|c|c|c|}
\hline Classifier & Example & Meaning \\
\hline /boh/ & /Sa boh gləh/ & One glass \\
& /dua boh a $\int \varepsilon a$ Ji Sumugroh/ & $\begin{array}{c}\text { The two dogs are } \\
\text { barking }\end{array}$ \\
\hline$/$ droe/ & /Sa droe/ & One person \\
\hline
\end{tabular}

Table 10. Acehnese Articles

\begin{tabular}{|c|c|}
\hline Sentence in English & Sentence in Acehnese \\
\hline The two dogs are barking. & /dua boh a fea Ji Sumugroh/ \\
\hline The book is good. & /buku nan gət/ \\
\hline
\end{tabular}

Table 11. the basic order of Acehnese

\begin{tabular}{|c|c|}
\hline $\begin{array}{c}\text { Sentence in } \\
\text { Acehnese }\end{array}$ & /lon lonłə? Sikula/ \\
\hline Meaning & I go to the school. \\
\hline
\end{tabular}


Table 12. The flexibility of Acehnese word order

\begin{tabular}{|c|c|c|}
\hline $\begin{array}{c}\text { Sentence in } \\
\text { Acehnese }\end{array}$ & $\begin{array}{l}\text { /kəh kəрəృоh bəh driən?/ } \\
\text { kəh?/ }\end{array}$ & / kәрәјоh bəh driən \\
\hline Meaning & \multicolumn{2}{|c|}{ Do you eat durian? } \\
\hline $\begin{array}{c}\text { Sentence in } \\
\text { Acehnese }\end{array}$ & $\begin{array}{l}\text { /lon lonjə? u kudd/ } \\
\text { kude lonjə?/ }\end{array}$ & u kude lon „əכ//lon u \\
\hline Meaning & \multicolumn{2}{|c|}{ I go to the market. } \\
\hline
\end{tabular}

Table 13. The intonation of Acehnese statement

\begin{tabular}{|c|c|}
\hline Statement in Acehnese & 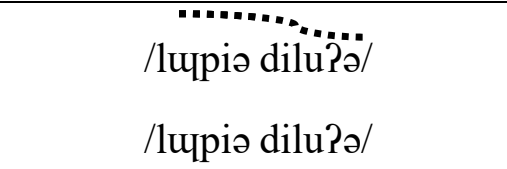 \\
\hline Statement in English & It is cold outside \\
\hline Statement in Acehnese & 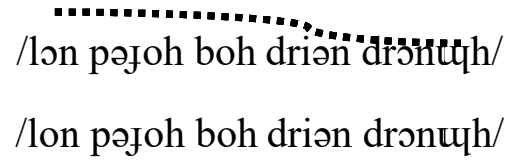 \\
\hline Meaning & I eat your durian. \\
\hline
\end{tabular}

Table 14. The intonation of Acehnese question

\begin{tabular}{|c|c|}
\hline Question in Acehnese & 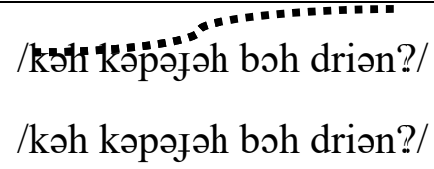 \\
\hline Meaning & Do you eat durian? \\
\hline
\end{tabular}


Table 15. word derivations in Arabic (Al-Muhtaseb \& Mellish 1998, p.8)

\begin{tabular}{|c|c|c|c|}
\hline Word \& Transliteration & Meaning & Word \& Transliteration & Meaning \\
\hline 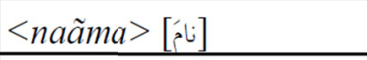 & He slept & <naã'imun> [نائl] & Sleeping \\
\hline 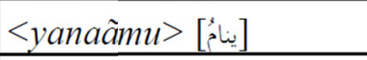 & He sleeps & 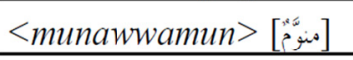 & Under hypnotic \\
\hline$<n a m>[\dot{i}]$ & Sleep & $<n a^{\prime} \mathbf{u} m u n>[;, j]$ & Late riser \\
\hline$<\tan w \bar{e} m u n>\left[{ }_{0}^{*}, 0\right]$ & Lulling to sleep & 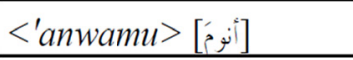 & More given to sleep \\
\hline 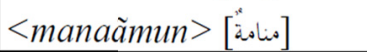 & Dream & $<$ nawwaãmun $>\left[\hat{n}\left[\begin{array}{l}* \\
0\end{array}\right]\right.$ & The most given to sleep \\
\hline$<$ nawmatun $>[0,0,0$ & Of one sleep & <manaãmun > [منام: [م] & Dormitory \\
\hline 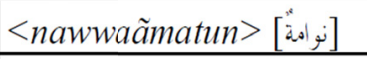 & Sleeper & <'an yanaãma > [أن ينام] & That he sleeps \\
\hline$<$ nawmiyyatun $>[0 ; 0$ & Pertaining to sleep & $<$ munawwamun $>\left[\begin{array}{l}{[0 .} \\
0\end{array}\right]$ & hypnotic \\
\hline
\end{tabular}

\section{Copyright Disclaimer}

Copyright for this article is retained by the author(s), with first publication rights granted to the journal.

This is an open-access article distributed under the terms and conditions of the Creative Commons Attribution license (http://creativecommons.org/licenses/by/3.0/). 